\title{
Kelas Ibu Meningkatkan Pengetahuan dan Keterampilan Ibu di Desa Soliu
}

\author{
Stefanus Mendes Kiik \\ Departemen Keperawatan Komunitas dan Keluarga, STIKes Maranatha Kupang; stefanusmendeskiik@ymail.com \\ (Koresponden) \\ Muhammad Saleh Nuwa \\ Departemen Keperawatan Medikal Bedah, STIKes Maranatha Kupang; musa.nuwa@gmail.com \\ Roslin E. M. Sormin \\ Departemen Kebidanan, STIKes Maranatha Kupang; roslin.sormin78@gmail.com
}

\begin{abstract}
The aim of this study was to investigate the effect of mother's class on the knowledge and the skills among mothers in Soliu Village. This pre-experimental with one group pre-and post-test design used in this research. To collect data, purposive sampling was taken, involving 20 respondents. A paired t-test was used to compare group differences in the knowledge, and the skills. There were significant improvements in the knowledge ( $p<0,001)$, and the skills $(p<0,001)$ among mothers.
\end{abstract}

Keywords: mother; knowledge; skills

\section{ABSTRAK}

Penelitian ini bertujuan untuk mengetahui pengaruh kelas ibu terhadap pengetahuan dan keterampilan ibu di Desa Soliu. Desain penelitian yang digunakan pada penelitian ini adalah pre-experimental dengan pendekatan one group pre and post test design. Teknik sampling yang digunakan dalam penelitian ini adalah purposive sampling. Sampel dalam penelitian ini berjumlah 20 orang. Paired t-test (dependent t-test) digunakan untuk membandingkan pengetahuan dan keterampilan sebelum dan sesudah perlakuan. Hasil penelitian menunjukkan bahwa kelas ibu berpengaruh signifikan meningkatkan pengetahuan $(\mathrm{p}<0,001)$ dan keterampilan ibu $(\mathrm{p}<0,001)$.

Kata kunci: ibu; pengetahuan; keterampilan

\section{PENDAHULUAN}

Selama beberapa dekade, Provinsi Nusa Tenggara Timur adalah daerah dengan AKI, AKB dan AKABA tertinggi di Indonesia, dengan AKB tahun 2017 sebesar 35 kematian per 1.000 kelahiran hidup, angka ini lebih tinggi dibandingkan AKB nasional yaitu 24 kematian per 1.000 kelahiran hidup. AKABA tahun 2017 sebesar 45 kematian per 1.000 kelahiran hidup, angka ini lebih tinggi dibandingkan AKB nasional yaitu 32 kematian per 1.000 kelahiran hidup ${ }^{(1)}$.

AKI Provinsi NTT pada periode 2004 - 2007 cenderung mengalami penurunan yang cukup bermakna. Pada tahun 2004 AKI NTT sebesar 554 per 100.000 kelahiran hidup (Surkesnas) dan menurun menjadi 306 per 100.000 kelahiran hidup pada tahun 2007. Tahun 2015, AKI di Provinsi NTT adalah sebesar 133/100.000 kelahiran hidup ${ }^{(2)}$. Angka tersebut masih di atas AKI nasional yaitu 126/100.000 kelahiran hidup ${ }^{(3,4)}$.

Tingginya angka kematian ini disebabkan oleh berbagai faktor seperti kunjungan ANC minimal 4 kali oleh tenaga kesehatan kompeten (66.8\%), yang di bawah rerata nasional (77.4\%). Tempat persalinan di fasilitas pelayanan kesehatan $(65.9 \%)$ dibanding persentase nasional $(79.4 \%)$. Penolong persalinan oleh tenaga kesehatan kompeten masih rendah $(72.6 \%)$ dibanding persentase nasional $(90.9 \%)$. Tidak dilakukan pemeriksaan oleh tenaga yang melakukan pemeriksaan pertama pada bayi baru lahir (2 hari pertama) lebih tinggi (27.8\%) dibanding persentase nasional (20.3\%). Masalah pelayanan jarak ke fasilitas pelayanan kesehatan (17.2\%) dibanding persentase nasional (10.9\%). Komplikasi kehamilan, kurangnya pengetahuan, sikap dan keterampilan ibu. BBLR mencapai 13.4\% dibanding persentase nasional (7.1\%). Praktik pemberian makanan pada bayi dan anak (PMBA) sesuai rekomendasi (34\%) lebih rendah dibanding persentase nasional (53.9\%). Anak usia 6-23 bulan yang mengkonsumsi makanan kaya vitamin A masih kurang $(79.4 \%)$ dibanding persentase nasional (86.2\%); makanan kaya zat besi $62.6 \%$ masih rendah dibanding persentase nasional (71.3\%). Persentase yang menerima vitamin A masa nifas sebesar 50.1\% masih kurang dibanding persentase nasional (52\%). Jumlah yang mengkonsumsi tablet atau sirup tambah darah selama masa kehamilan (lengkap 90 hari atau lebih) sebesar $39.8 \%$ lebih rendah dibanding persentase nasional $(43.9 \%)^{(1)}$.

Ada tiga faktor utama penyebab kematian ibu dan bayi; 1) faktor medik, 2) faktor sistem pelayanan (sistem pelayanan antenatal, persalinan, pasca persalinan dan kesehatan anak), dan 3) faktor ekonomi, sosial budaya dan peran serta masyarakat (kurangnya pengenalan masalah, terlambatnya proses pengambilan keputusan, kurangnya akses terhadap pelayanan kesehatan, dan peran masyarakat dalam kesehatan ibu dan anak) ${ }^{(5)}$.

Salah satu peran serta masyarakat adalah ibu dan keluarga. Pengetahuan dan keterampilan ibu sangat penting selama masa kehamilan, persalinan, nifas, perawatan bayi dan balita. Kelas ibu merupakan kelompok kelompok belajar ibu-ibu hamil, ibu menyusui dan ibu balita ${ }^{(6)}$. Di kelas ini ibu-ibu akan belajar bersama, berdiskusi dan tukar pengalaman tentang kesehatan Ibu dan anak (KIA) secara menyeluruh dan sistematis serta dapat dilaksanakan secara terjadwal dan berkesinambungan. Kelas ibu hamil difasilitasi oleh bidan dengan menggunakan paket kelas ibu yaitu buku KIA, pedoman pelaksanaan kelas ibu hamil ${ }^{(7)}$, pedoman penyelenggaraan kelas ibu balita, ibu hamil dan ibu menyusui( ${ }^{(6)}$, 
pegangan fasilitator kelas ibu ibu balita ${ }^{(8)}$. Kelas ibu menyediakan informasi untuk ibu selama kehamilan, nifas maupun selama masa perawatan bayi dan balita. Pelayanan kesehatan termasuk antenatal harus berbasis kebutuhan ibu ${ }^{(9)}$. Tujuan penelitian ini adalah untuk mengetahui pengaruh kelas ibu terhadap pengetahuan dan keterampilan ibu di Desa Soliu.

\section{METODE}

Desain penelitian ini adalah pre-experimental berupa one group pre and post test design, dilakukan pada bulan Mei sampai Juni 2019 di Desa Soliu, Kabupaten Kupang. Sampel dengan ukuran 20, dipilih dengan teknik purposive sampling. Fasilitor kelas ibu adalah dua orang bidan berpengalaman. Instrumen pengumpulan data adalah kuesioner tentang umur, jumlah anak dan pendidikan terakhir, kuesioner pengetahuan (20 item) dan lembar observasi keterampilan (12 item). Uji normalitas data menggunakan Shapiro-Wilk test, sedangkan pengujian hipotesis menggunakan Paired sample t-test (membandingkan pengetahuan dan keterampilan sebelum dan sesudah perlakuan ${ }^{(10,11)}$.

\section{HASIL}

Tabel 1. Karakteristik responden berdasarkan usia di Desa Soliu

\begin{tabular}{|c|c|c|}
\hline Variabel & Mean & SD \\
\hline Usia & 31,00 & 7.83 \\
\hline
\end{tabular}

Tabel 2. Karakteristik responden berdasarkan tingkat pendidikan dan jumlah anak di Desa Soliu

\begin{tabular}{|l|c|c|}
\hline \multicolumn{1}{|c|}{ Karakteristik } & Frekuensi & Persentase \\
\hline Tingkat Pendidikan & 5 & \\
Sekolah Dasar & 5 & 25 \\
Sekolah Menengah Pertama & 6 & 30 \\
Sekolah Menegah Atas & 5 & 20 \\
Sarjana/Diploma III & 5 & 25 \\
\hline Jumlah anak & 8 & 25 \\
Satu anak & 2 & 40 \\
Dua Anak & 4 & 10 \\
Tiga anak & 1 & 20 \\
Empat Anak & 5 \\
Lima Anak & \\
\hline
\end{tabular}

Rerata responden berusia $31( \pm 7.83)$ tahun. Hasil tersebut sejalan dengan SDKI di mana wanita kawin yang berusia 20-34 tahun lebih banyak yang berusia 30-34 tahun dibanding kelompok usia 20-24 maupun 25-29 tahun. Pendidikan responden merata antara masing-masing tingkat pendidikan namun pendidikan terbanyak adalah sekolah menengah pertama (30\%). Hal ini sejalan dengan hasil SDKI tahun 2017 menunjukkan bahwa rerata pendidikan perempuan yang tinggal di pedesaan lebih banyak yang tamat SD dan tidak tamat SMA. Desa Soliu termasuk daerah pedesaan sehingga akses terhadap pendidikan masih kurang. Persentase jumlah anak terbanyak adalah dua anak (40\%) dan terendah adalah lima anak $(5 \%)$.

Tabel 3 menunjukkan rerata pengetahuan ibu sesudah perlakuan lebih tinggi yaitu 81,50 dengan standar deviasi 6,90 dibandingkan sebelum perlakuan yaitu 50,25 dengan standar deviasi 16,34. Rerata pengetahuan meningkat 31,25 poin pada rentang skor 0-100. Hasil uji lebih lanjut menggunkan paired t-test didapatkan $\mathrm{p}<0,001$. Hal ini berarti pengetahuan ibu lebih baik sesudah dilakukan kelas ibu. Hal ini juga berarti ada perbedaan signifikan pengetahuan ibu setelah intervensi.

Tabel 3. Pengaruh kelas ibu terhadap pengetahuan dan keterampilan ibu di Desa Soliu

\begin{tabular}{|c|l|c|c|c|}
\hline Variabel & \multicolumn{1}{|c|}{ Pengukuran } & Mean & SD & p value \\
\hline \multirow{2}{*}{ Pengetahuan Ibu } & Pre Tes $(\mathrm{n}=20)$ & 50.25 & 16.34 & $<0.001$ \\
\cline { 2 - 5 } & Post Tes $(\mathrm{n}=20)$ & 81.50 & 6.90 & \\
\hline \multirow{2}{*}{ Keterampilan Ibu } & Pre Tes $(\mathrm{n}=20)$ & 43.75 & 12.20 & $<0.001$ \\
\cline { 2 - 4 } & Post Tes $(\mathrm{n}=20)$ & 80.21 & 9.16 & \multirow{2}{*}{} \\
\hline
\end{tabular}

Rerata keterampilan ibu sesudah perlakuan lebih tinggi dibandingkan dengan sebelum perlakuan. Hasil pairedsample t-test adalah $\mathrm{p}<0,001$. Hal ini berarti keterampilan ibu lebih baik sesudah dilakukan kelas ibu. Hal ini juga berarti ada perbedaan signifikan keterampilan ibu setelah intervensi.

\section{PEMBAHASAN}

Hasil penelitian menunjukkan bahwa kelas ibu dapat meningkatkan pengetahuan ibu, antara lain dalam hal (1) pengaturan kelahiran; (2) pemeriksaan kehamilan; (3) makanan yang sehat bagi ibu hamil; (4) menjaga kebersihan diri; (5) mengenali tanda-tanda bahaya pada ibu hamil; (6) mengenali tanda-tanda persalinan; (7) mengenali tanda-tanda bahaya pada ibu bersalin; (8) yang harus dilakukan oleh ibu nifas tentang asi; (9) menjaga kesehatan pada ibu nifas; (10) mengenali tanda-tanda bahaya pada ibu nifas; (11) teknik menyusui yang benar; (12) pola makan anak; (13) tumbuh kembang anak; (14) pemberian kapsul vitamin A; (15) imunisasi lengkap untuk bayi. Hal ini sejalan dengan ${ }^{(12)}$ bahwa kelas ibu dapat meningkatkan pengetahuan ibu dalam pemanfaatan buku KIA. Clementina et al (2016) bahwa pendidikan kesehatan ibu dapat meningkatkan pengetahuan ibu-ibu yang mengikuti ANC di Nigeria ${ }^{(13)}$. 
Evaluasi output kelas ibu balita di Kabupaten Banjarnegara yang ditunjukkan nilai pre-test dan post-test peserta terhadap materi yang diberikan oleh fasilitator sebanyak $58,41 \%$ nilainya meningkat ${ }^{(14)}$. Hasil penelitian juga diperkuat oleh ${ }^{(15)}$ bahwa pelaksanaan kelas ibu hamil meningkatkan pengetahuan tentang persiapan persalinan pada 36 ibu hamil di Bolaang Mongondow. Ibu hamil, ibu menyusui dan ibu balita dengan pengetahuan yang baik lebih siap selama masa kehamilan, persalinan, nifas, perawatan bayi dan balita. Ini berdampak pada penurunan kematian ibu, bayi dan balita.

Materi kelas ibu ini bersumber dari modul dari Kemenkes RI. Modul tersebut sangat bermanfaat karena berisi panduan baik bagi fasilitator maupun bagi peserta. Semua peserta yang telah dibagikan modul dapat mempelajari modul tersebut di rumah setelah kegiatan kelas ibu dilakukan. Hasil penelitian yang dilakukan oleh ${ }^{(16)}$ menunjukkan bahwa penggunaan modul pada saat ANC oleh 62 ibu primigravida di India dapat meningkatkan pengetahuan.

Pengetahuan yang memadai tentang kehamilan, persalinan, asi eksklusif, perawatan bayi dan balita menjadi dasar bagi ibu untuk melakukan upaya peningkatan kesehatan. Hasil penelitian ${ }^{(17)}$ menyebutkan bahwa pengetahuan ibu tentang perawatan BBLR yang baik dapat meningkatkan berat badan bayi. Pengetahuan ibu yang baik juga memiliki hubungan yang signifikan dengan pemberian MPASI dini pada bayi usia kurang dari enam bulan ${ }^{(18)}$.

Keterampilan ibu dalam melakukan teknik menyusui yang benar meningkat signifikan. Ibu-ibu mampu mempraktikkan teknik menyusui yang benar. Hal ini menunjukkan bahwa kelas ibu dapat meningkatkan selain pengetahuan juga keterampilan. Penelitian lain menunjukkan bahwa teknik menyusui yang benar meningkatkan keberhasilan laktasi. Hal ini berarti bayi mendapatkan ASI secara eksklusif meningkat ${ }^{(19)}$.

\section{KESIMPULAN}

Kelas ibu dapat meningkatkan pengetahuan dan keterampilan ibu secara signifikan. Rerata pengetahuan dan keterampilan ibu setelah kelas ibu lebih tinggi dibanding sebelum kelas ibu dilakukan.

\section{DAFTAR PUSTAKA}

1. Kemenkes RI, BKKBN, BPS, USAID. Survei Demografi Dan Kesehatan Indonesia 2017. Jakarta: Kemenkes RI, BKKBN, BPS dan USAID; 2018.

2. Dinkes Prov NTT. Profil Kesehatan Provinsi Nusa Tenggara Timur 2015. Kupang: Dinkes Prov. NTT; 2015

3. WHO. Trends in Maternal Mortality: 1990 to 2015: Estimates Developed by WHO,UNICEF,UNFPA, The World Bank and the United Nations Population Divisions. Geneva: WHO; 2015.

4. Tauho KD, Karwur FF. An Insight Into Maternal Death Caused By Postpartum Hemorrhage in Western Timor, Indonesia. J Keperawatan Indones. 2019;22(1):1-10.

5. Nurrizka RH, Saputra W. Arah dan Strategi Kebijakan Penurunan Angka Kematian Ibu (AKI), Angka Kematian Bayi (AKB) dan Angka Kematian Balita (AKABA) di Indonesia. Prakarsa.

6. Kemenkes RI. Pedoman penyelenggaraan kelas ibu balita, ibu hamil \& ibu menyusui. Jakarta: Kemenkes RI; 2011.

7. Kemenkes RI. Buku Pedoman Pelaksanaan Kelas Ibu Hamil. Jakarta: Kementerian Kesehatan RI; 2014.

8. Kemenkes RI. Pegangan fasilitator kelas ibu. Jakarta: Kementerian Kesehatan RI; 2009.

9. Almalik MMA, Mosleh SM. Pregnant women: What do they need to know during pregnancy? A descriptive study. Women and Birth. Australian College of Midwives; 2017;30(2):100-6.

10. Grove SK, Gray JR. Understanding Nursing Research: Building an Evidence-Based Practice- 7th Edition. Elsevier. Philadelphia: Elsevier Ltd; 2018.

11. Polit DF, Beck CT. Essentials of Nursing Research Appraising Evidence for Nursing Practice. Ninth edit. Philadelphia: Wolters Kluwer Health; 2018.

12. Ningtyas SF. Pengaruh Kelas Ibu Balita Usia 0-59 Bulan Terhadap Pengetahuan Pemanfaatan Buku KIA. J Keperawatan dan Kebidanan. 2015;8(1):63-71.

13. Clementina U, Jerome O, Monica C, John E, Edith N, Oluchukwu L. Effect Of Maternal Health Education On The Health Knowledge Of Pregnant Mothers Attending Ante-Natal Clinics In Anambra. IOSR J Nurs Heal Sci. 2016;5(1):56-63.

14. Ratmawati LA. Evaluasi program pelaksanaan kelas ibu balita di wilayah kerja dinas kesehatan kabupaten banjarnegara. J Kebidanan dan Keperawatan Aisyiyah. 2018;14(1):25-31.

15. Lucia S, Purwandari A, Pesak E. Pengaruh Pelaksanaan Kelas Ibu Hamil Terhadap Pengetahuan Tentang Persiapan Persalinan. J Ilm Bidan [Internet]. 2015;3(1):61-5. Available from: https://ejurnal.poltekkesmanado.ac.id/index.php/jidan/article/view/361

16. Nidhi N. Effectiveness of self-instructional module on knowledge and attitude regarding antenatal care among primigravida mothers in selected government hospital, Dehradun, Uttarakhand. Int J Med Sci Public Heal. 2018;7(11):651.

17. Ningsih SR, Suryantoro P, Nurhidayati E. Hubungan pengetahuan ibu tentang perawatan bayi berat lahir rendah (BBLR) dengan kenaikan berat badan bayi. J Kebidanan dan Keperawatan Aisyiyah. 2016;12(2):149-57.

18. Nababan L, Widyaningsih S. Pemberian MPASI dini pada bayi ditinjau dari pendidikan dan pengetahuan ibu. J Kebidanan dan Keperawatan Aisyiyah. 2018;14(1):32-9.

19. Arismawati DF, Effendy HV. Hubungan Teknik Menyusui yang Benar dengan Tingkat Keberhasilan Laktasi. J Keperawatan Kebidanan. 2014;6(1):22-30. 